\title{
Contraceptive uptake among women attending family planning clinic in a Nigerian tertiary health facility: a 6 year review
}

\section{Adebimpe O. Ijarotimi ${ }^{1}$, Babatola Bakare ${ }^{2}$, Olusegun O. Badejoko ${ }^{1}$, Akintunde O. Fehintola ${ }^{1}$, Olabisi M. Loto ${ }^{1}$, Earnest O. Orji ${ }^{1}$, Abiodun S. Adegoke ${ }^{1}$}

\author{
${ }^{1}$ Department of Obstetrics, Gynaecology and Perinatology, Obafemi Awolowo University/Teaching Hospitals \\ Complex, Ile-Ife, Osun- State, Nigeria \\ ${ }^{2}$ Department of Obstetrics \& Gynaecology, State Hospital, Ondo, Ondo-State, Nigeria
}

Received: 30 March 2015

Accepted: 09 May 2015

\author{
*Correspondence: \\ Dr. Babatola Bakare, \\ E-mail: lobak4christ@gmail.com
}

Copyright: (c) the author(s), publisher and licensee Medip Academy. This is an open-access article distributed under the terms of the Creative Commons Attribution Non-Commercial License, which permits unrestricted non-commercial use, distribution, and reproduction in any medium, provided the original work is properly cited.

\begin{abstract}
Background: Contraceptive uptake is one of the most important determinants of pregnancy rates and birth rates in the world. Aim: To determine the principal trends in contraceptive use from 2004-2009 in the family planning unit of a tertiary health centre in South-Western Nigeria, and to identify the effect of age, marital status and parity on the choice of contraceptive method.

Methods: The record of 1,862 clients attending the Family Planning unit of Obafemi Awolowo University Teaching Hospitals Complex, Ile-Ife, Osun-State, Nigeria for the period between 2004-2009 were reviewed. Information related to the age, marital status, parity and the choice of contraception were obtained using a structured proforma and the data analyzed with SPSS version 16. Pearson chi-square test was used as test of significance where applicable.

Results: Within the study period, the contraceptive uptake was $13.2 \%$. Copper-T IUCD was the most commonly used method of contraception (77.9\%), followed by the progestogen only injectable contraceptives (12.6\%), then oral pills $(4.1 \%)$ and progestin implants $(2.3 \%)$. Single women and women of low parity are more likely to use pills than IUCD (69\% vs. 38.3\%) while long acting reversible contraception (injectables and IUCD) are preferred by women with higher parity $(\mathrm{P}=0.000)$.

Conclusions: IUCD is the most popular method of contraception in Ife-Ijesha area of Nigeria. Contraceptive uptake is relatively low among the women. Age and parity are key influences on the uptake and choice of contraception practiced by the women, while the influence of marital status is not statistically significant.
\end{abstract}

Keywords: Contraception, Choice, Uptake

\section{INTRODUCTION}

Contraception has been defined by the World Health Organization (WHO) as a means of preventing pregnancy despite the act of coitus by interrupting the chain of events between male and female gamete that leads to fertilization.
Maternal mortality can only occur in the presence of a pregnancy. Family planning is therefore an indispensable tool in reducing maternal mortality and morbidity. Quite a number of studies from Africa have shown that most women are in favour of family planning and are reasonably well informed about the various methods of contraception. $^{1-5}$ Contraceptive uptake is one of the most important determinants of pregnancy rates and birth rates in the world, so contraceptive profiles provide useful 
information about how women and their partners control fertility, what family planning clients may need, whether provider caseloads are typical of the National Population and whether the contraceptive needs of important subpopulations are being met. ${ }^{6}$

The choice of a contraceptive method has been shown to be affected by many factors including age, race, socioeconomic status, medical risks, health status, involvement in a sexual relationship, media exposure and confidentiality of services. $^{7-9}$

The aim of this study was to determine the principal trends in contraceptive use among the women accessing family planning services between the period of 20042009 in the family planning unit of a tertiary health institution in South-Western Nigeria, and to identify the effect of age, marital status and parity on the choice of contraceptive method.

Obafemi Awolowo University Teaching Hospitals Complex, Ile-Ife, Osun State Nigeria consists of two hospitals and two primary health care centres. These hospital units serve not only the Ife-Ijesa health administrative zone in which they are located, but also receive clients from other parts of Osun State and some parts of Oyo, Ondo and Ekiti States which are neighbouring states.

\section{METHODS}

A retrospective record of 1862 women who attended the family planning units of the hospital was collected for the period between years 2004-2009. Information about age, marital status, parity and choice of contraception were extracted using a structured proforma. Analysis was done with respect to contraceptive prevalence use over the years of study. The influence of age, parity and marital status was considered on the choice and patterns of contraceptive use. Data was analyzed with SPSS version 16, Pearson Chi-square test was used as test of significance where applicable and a $\mathrm{P}$ value $<0.05$ was considered statistically significant.

\section{RESULTS}

Within the study period, 1862 women visited and obtained various forms of contraceptives from the Family planning clinic while a total of 12,290 women visited the general gynaecology out-patient clinic; giving an uptake of $13.2 \%$. The available modern methods of contraception at the center were: Copper T-Intrauterine Contraceptive Device (IUCD), Progestogen-only injectables, combined oral contraceptive pills (Pills), progestin implants, male and female condoms, spermicides and Bilateral Tubal Ligation (BTL).

Table 1 shows the frequency table for the various contraceptive methods obtained at the clinic over the study period. One thousand, four hundred and fifty
(77.9\%) of the clients opted for Intrauterine Contraceptive Device (IUCD) followed by the injectables $(12.6 \%)$, then the oral pills $(4.1 \%)$ and the progestin implants (2.3\%). Less popular were condoms, spermicides and female sterilization $(1.6 \%, 0.1 \% \& 0.1 \%$ respectively).

Table 1: Contraceptive options and uptake.

\begin{tabular}{|lll|}
\hline Contraceptives & Frequency & Percentage (\%) \\
\hline IUCD & 1450 & 77.9 \\
\hline PILLS & 77 & 4.1 \\
\hline Progestin injectables & 234 & 12.6 \\
\hline Male condom & 15 & 0.8 \\
\hline Female condom & 14 & 0.8 \\
\hline BTL & 1 & 0.1 \\
\hline No method & 28 & 1.5 \\
\hline Foam (Spermicides) & 1 & 0.1 \\
\hline Implant & 42 & 2.3 \\
\hline Total & 1862 & 100.0 \\
\hline
\end{tabular}

The age of the clients ranged between 18 and 60 years with a mean of 33.19 and Standard Deviation (SD) of 6.91. The age for 9 of the clients was not specified. It was also discovered as shown in Table 2 that, women within 20-49 years age bracket were more active in the practice of modern contraceptives during the study period as against women outside this age group who are mainly adolescents and the elderly.

Table 2: Age distribution \& contraceptive uptake.

\begin{tabular}{|lll|}
\hline Age group & Frequency & Percent \\
\hline$<20$ & 12 & 0.6 \\
\hline $20-29$ & 554 & 29.8 \\
\hline $30-39$ & 956 & 51.3 \\
\hline $40-49$ & 285 & 15.3 \\
\hline$>50$ & 46 & 2.5 \\
\hline Unspecified & 9 & 0.5 \\
\hline Total & 1862 & 100 \\
\hline Mean \pm SD & 33.19 & 6.91 \\
\hline
\end{tabular}

Table 3 shows the effect of marital status on uptake and choice of contraception. Married women accounted for $1834(98.5 \%)$ of the clients, $26(1.4 \%)$ were unmarried, while $2(0.1 \%)$ were widows.

Table 3: Marital status and contraceptive uptake.

\begin{tabular}{|lll|}
\hline Marital status & Erequency & Percent \\
\hline Married & 1834 & 98.5 \\
\hline Single & 26 & 1.4 \\
\hline Widowed & 2 & 0.1 \\
\hline Total & 1862 & 100 \\
\hline
\end{tabular}

The parity of the clients ranged from 0-11 with a mean and standard deviation of 3.07 and 1.58 respectively. Table 4 shows that contraceptive uptake increases with 
parity up to $\mathrm{P}_{5}$ and subsequently falls. Seventeen (0.9\%) of the clients were nulliparous, majority (80.8\%) were between para 1-4 while Para 5 and above were 341 $(18.3 \%)$.

Table 4: Parity and contraceptive uptake.

\begin{tabular}{|lll|}
\hline Parity & Frequency & Percentage \\
\hline 0 & 17 & 0.9 \\
\hline 1 & 307 & 16.5 \\
\hline 2 & 400 & 21.5 \\
\hline 3 & 430 & 23.1 \\
\hline 4 & 367 & 19.7 \\
\hline $5 \&>$ & 341 & 18.3 \\
\hline Total & 1862 & 100 \\
\hline Mean \pm SD & 3.07 & 1.58 \\
\hline
\end{tabular}

Table 5 shows that women of low parity $\left(\mathrm{P}_{0-2}\right)$ are more likely to use pills as opposed to IUCD (69\% \& $38.3 \%$ respectively). The reverse is observed in women of high parity $\left(>\mathrm{P}_{2}\right)$ which is $61.6 \%$ \& $31.2 \%$ for IUCD \& pill respectively, $\mathrm{P}$ value $=0.000$. Marital status, however does not have a significant effect on the choice of contraception $(\mathrm{P}=0.071)$.

Table 5: Influence of age, parity and marital status on contraceptive choice.

\begin{tabular}{|c|c|c|}
\hline & $\begin{array}{l}\text { IUCD (\%), } \\
(n=1450)\end{array}$ & $\begin{array}{l}\text { Pills (\%) } \\
(\mathrm{n}=77)\end{array}$ \\
\hline \multicolumn{3}{|c|}{ Age (years) } \\
\hline$<40$ & $1154(79.6)$ & $76(98.7)$ \\
\hline$>40$ & $296(20.4)$ & $1(1.3)$ \\
\hline Mean \pm SD & $33.2 \pm 6.9$ & \\
\hline P value & 0.000 & \\
\hline \multicolumn{3}{|l|}{ Parity } \\
\hline $0-2$ & $570(39.3)$ & $53(68.9)$ \\
\hline$>2$ & $880(60.7)$ & $24(31.1)$ \\
\hline Mean \pm SD & $3.1 \pm 1.6$ & \\
\hline$P$ value & 0.000 & \\
\hline \multicolumn{3}{|c|}{ Marital status } \\
\hline Married & $1409(97.2)$ & 73 (93.5) \\
\hline Single & $41(2.8)$ & $5(6.5)$ \\
\hline P value & 0.071 & \\
\hline
\end{tabular}

\section{DISCUSSION}

Within the study period, 1862 women visited and obtained various forms of contraceptives from the Family Planning clinic while a total of 12,290 women visited the general gynaecology out-patient clinic; giving a contraceptive prevalence rate of $13.2 \%$.

From the available methods, IUCD was the most popular choice accounting for $77.9 \%$ of the clients, followed by the injectables $(12.6 \%)$, then the oral contraceptive pills $(4.1 \%)$ and progestin implants $(2.3 \%)$. Less popular were Condoms, spermicides and female sterilization (1.5\%,
$0.1 \% \& 0.1 \%$ respectively). This may probably reflect the relative availability of each method \& cost variations. The invasive nature of BTL, religious beliefs and cost consideration may contribute to making it less acceptable compared to the other methods available. The trend of contraceptive choice with IUCD in the lead, followed by injectables; then oral contraceptive pills as the $3^{\text {rd }}$ preferred choice and condoms among the less preferred is similar to the trend found at the family planning clinics of Lagos University Teaching Hospital (LUTH) and Ladoke Akintola University of Technology (LAUTECH) Teaching Hospital, Osogbo; both in Southwestern Nigeria. $^{10,11}$

The finding that majority of our clients prefer IUCD is in keeping with results of similar studies from other centers in Nigeria. ${ }^{10,12-15}$ This is also supported by the fact that Intrauterine contraceptive devices are the most widely used reversible contraceptives in the world, and it had been estimated that over 130 million women of reproductive age were using IUDs for birth control. ${ }^{15}$ Progestogen-only injectables uptake of $12.6 \%$ found in this study is lower than $71.8 \%$ found in Aba (Southeastern Nigeria) ${ }^{17}$ but comparable to $14.2 \%$ reported from Jos (North-central Nigeria). ${ }^{18}$ Regional variability may be responsible for this. Uptake of female condoms by clients in this study compared surprisingly well with male condoms $(0.8 \%$ vs. $0.8 \%)$ considering the fact that female condoms entered most family planning programmes in developing countries much later than the male prototype. However, on the whole; Condoms as a contraceptive option is less popular among the study population compared to IUCD and hormonal contraception. This is supported by similar findings from other centers in Osogbo and Lagos (southwestern Nigeria). ${ }^{10,11}$

Women within 30-39 years age bracket were more active in the practice of modern contraceptives during the study period as against women outside this age group. This agreed with findings reported by Adeyemi et al. in Osogbo (Southwestern Nigeria). ${ }^{10}$ This is not surprising since this age bracket represents the peak reproductive period with more women deferring child bearing to their 30 s in pursuit of education and career. In women above 39 years of age, use of the IUCD competes almost equally with condom for the most commonly selected method. For this age group in which the risk of medical contraindications to combined oral contraceptive pills is most likely, the IUCD seems to be considered a more favourable option. Also older women are more likely to consider the need for long term contraception. Moreover, their greater likelihood of being in stable monogamous sexual relationships than younger women reduces the risks of exposure to sexually transmitted diseases and makes the selection of IUCD more likely.

Contraceptive uptake is relatively low among the singles (1.4\%) compared to the married $(98.5 \%)$. This may be due to the fact that single women are less likely to source for contraception openly because of cultural and religious prohibition of premarital sex in this part of the world. 
Contraceptive uptake increases with parity up to $\mathrm{P}_{3}$ and subsequently falls. This may reflect the reproductive need of women in this age group as women with parity below 3 are likely to be sexually active and at the peak of their reproductive career while the grand multipara are more likely to be perimenopausal. Women of low parity $\left(<\mathrm{P}_{2}\right)$ are more likely to use pills as opposed to IUCD (69\% vs. $38.3 \%$ respectively). The reverse is observed in women of high parity $\left(>\mathrm{P}_{3}\right)$ which is $61.6 \% \& 31.2 \%$ for IUCD $\&$ pills respectively. Although IUCD is the most preferred method by parous women in Nigeria and other developing countries, nulliparity is no longer considered to be a contraindication to its use. ${ }^{19-21}$

Family planning is a veritable tool in the efforts geared at improving maternal health, reducing maternal \& underfive mortality. To reach these goals, there is a need to improve access, availability and delivery of family planning services across the nation for all women in the reproductive age group and their partners. 'That Mothers May Live to Care for Their Children.'

\section{Funding: No funding sources}

Conflict of interest: None declared

Ethical approval: The study was approved by the institutional ethics committee

\section{REFERENCES}

1. Adinma JIB, Nwosu BO. Family planning knowledge and practice among women attending an antenatal clinic. Adv Contracep. 1995;11:335-44.

2. Ntozi JPM, Kabara JB. Family planning in rural Uganda: Knowledge and use of modern and traditional methods in Ankole. Stud Fam Plann. 1991;22:116-23.

3. Einterz EM. Family planning and tradition: a view from northern Cameroon. World Health Forum. 1994; 15:378-81.

4. Aja GH, Nwangwa MA, Egwu IN. Knowledge, attitude and practice of family planning in rural communities in Nigeria. Asia Pac J Public Health. 1995;8:85-90..

5. Ukaegbu AO. Family planning attitudes and practices in rural eastern Nigeria. Stud Fam Plann. 1977;8:177-83.

6. Ventura SV, Mosher WD, Curtin SD, Martin JA, Mathews TJ. Trends in pregnancies and pregnancy rates: estimates for the United States, 1980-1992. Monthly Vital Statistics Report. 1995;43(11 Suppl 2):260.

7. Westoff CF, Jones EF. Contraception and sterilization in the United States, 1965-1975. Fam Plann Perspect. 1977;1:153-7.

8. Zelnick M, Kantner JF. Sexual activity, contraceptive use and pregnancy among metropolitan
- area teenagers: 1971-1979. Fam Plann Perspect. 1980;12:230-7.

9. Forrest JD, Henshaw SK. What US women think and do about contraception. Fam Plann Perspect. 1983;15:157-66.

10. Adeyemi AS, Adekanle DA. Factors influencing the choice of contraceptives among the married women in Osogbo, Western Nigeria. Niger Med Practitioner. 2009;55(4):56-60.

11. Ogedengbe OK, Giwa-Osagie OF, Ola R, Fasan MO. Contraceptive choice in an urban clinic in Nigeria. $\mathrm{J}$ Biosoc Sci. 1987;19:89-95.

12. Cameroon. Demographic and health survey (D.H.S), 1991. A Survey. B. P. 7094 Yaounde, Cameroon: National Department of the Second General Population and Housing Census (2nd GPHC); 1992.

13. United Nations Department of Economic and Social Affairs, Population Division. World contraceptive use 2005. In: UN, eds. Publication ST/ESA/SER. A/253. New York: United Nations; 2006.

14. Foran TM. New contraceptive choices across reproductive life. Med J Aust. 2003;178:616-20.

15. Herbert B, Peterson HB, Curtis KM. Contraception. In: James R. Scott, Ronald S. Gibbs, Beth Y. Karlan, Arthur F. Haney, eds. Danforth's Obstetrics and Gynaecology. 9th ed. Philadelphia: Lippincott Williams \& Wilkins Publishers; 2003: 37.

16. Mishell DR. Intrauterine devices: mechanisms of action, safety and efficacy. Contraception. 1998;58:545-53.

17. Chigbu B, Onwere S, Aluka C, Kamanu C, Okoro O, Feyi-Waboso P. Contraceptive choices of women in rural southeastern Nigeria. Niger J Clin Pract. 2010;13:195-9.

18. Mutihir JT, Pam VC. Overview of contraceptive use in Jos University teaching hospital, North Central Nigeria. Niger J Clin Pract. 2008;11:139-43.

19. Adeyemi AS, Adekanle DA. Pattern of contraceptive choice among the married women attending the family planning clinic of a tertiary health institution. Niger J Med. 2008;17:67-70.

20. Hubacher D, Lara-Ricalde R, Taylor DJ, GuerraInfante F, Guzmán-Rodríguez R. Use of copper intrauterine devices and the risk of tubal infertility among nulligravid women. $\mathrm{N}$ Engl $\mathrm{J}$ Med. 2001;345:561-7.

21. Lete I, Morales P, De Pablo JL. Use of intrauterine contraceptive devices in nulliparous women: personal experience over a 12-year period. Eur J. Contracept Reprod Health Care. 1998;3:190-3.

DOI: $10.18203 / 2320-1770 . i j r \operatorname{cog} 20150080$

Cite this article as: Ijarotimi AO, Bakare B, Badejoko OO, Fehintola AO, Loto OM, Orji EO, Adegoke AS. Contraceptive uptake among women attending family planning clinic in a Nigerian tertiary health facility: a 6 year review. Int J Reprod Contracept Obstet Gynecol $2015 ; 4: 721-4$ 